\title{
TRANSFORMATION OF THE JERUZALEM HILLS CULTURAL LANDSCAPE WITH MODERN VINEYARD TERRACES
}

Primož Pipan, Žiga Kokalj

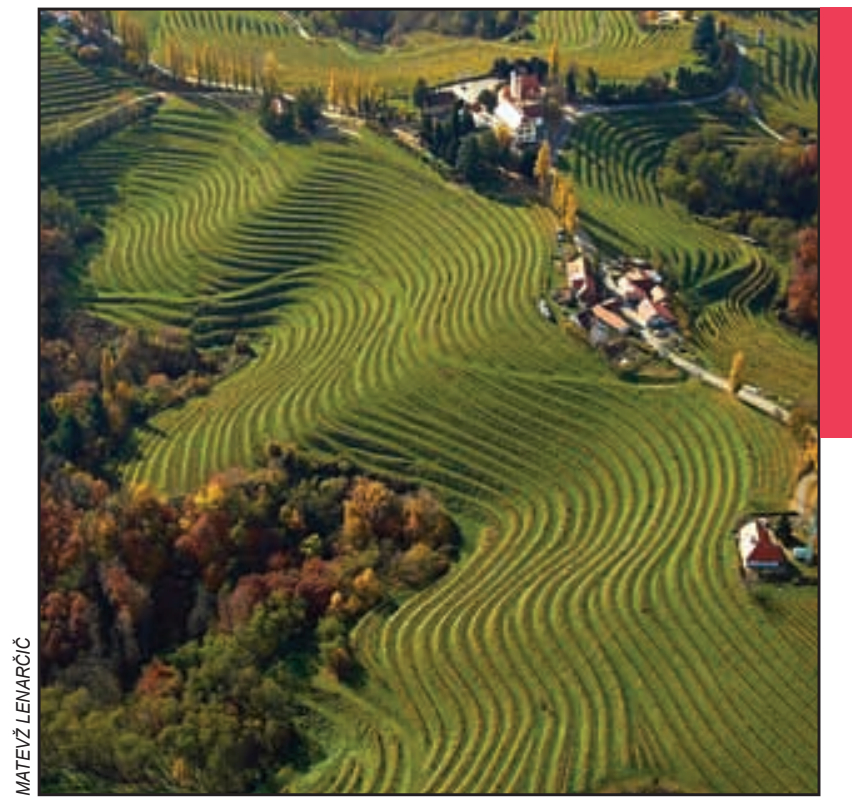

The dimensions, form, and inclination of terrace platforms and slopes are completely adapted to the terrain, steepness, and lithological and pedological conditions. Terrace access also depends on these. 


\section{Transformation of the Jeruzalem Hills cultural landscape with modern vineyard terraces}

DOI: http://dx.doi.org/10.3986/AGS.4629

UDC: 911.53:631.613(497.412)

COBISS: 1.01

ABSTRACT: The terraced landscape in the Jeruzalem Hills is the result of specific socioeconomic conditions under communism, and now its appearance is drastically changing for the second time in the last fifty years. This article examines the creation of the new landscape layer of modern cultivated terraces and studies their disappearance and the return to a condition similar to the original state. The analysis is based on interviews and visual interpretation of aerial laser scanning (lidar) data. It focuses on the state of the landscape before terracing, the creation of terraces and formation of a terraced landscape, and its most recent transformation into slopes without terraces. It is determined that, despite the recognized aesthetic value of terraces, legal protection in the form of a nature park has not impacted their preservation because $56 \%$ of them have already been leveled. With the conversion of vineyards to vertical plantations, a new challenge is arising: increased erosion.

KEY WORDS: geography, terraces, terraced landscape, transformation of cultural landscape, visual interpretation of lidar, Jeruzalem Hills, Slovenia

The article was submitted for publication on July $19^{\text {th }}, 2016$.

\section{ADDRESSES:}

Primož Pipan, Ph.D.

Anton Melik Geographical Institute

Research Center of the Slovenian Academy of Sciences and Arts

Gosposka ulica 13, SI - 1000 Ljubljana

E-mail: primoz.pipan@zrc-sazu.si

\section{Žiga Kokalj, Ph.D.}

Institute of Anthropological and Spatial Studies

Research Center of the Slovenian Academy of Sciences and Arts

Novi trg 2, SI - 1000 Ljubljana

E-mail: ziga.kokalj@zrc-sazu.si 


\section{Introduction}

The abandonment of farming on traditional agricultural terraces that were created for manual cultivation and are thus less suitable for mechanical cultivation is connected with migration to urban areas. At the global level, terraced landscapes with permanently abandoned terraces are especially common in the Andes in South America (Guillet et al. 1987; Denevan 1988; Goodman Elgar 2008) and in the European Mediterranean area (García-Ruiz and Lana-Renault 2011; Stanchi et al. 2012; Lasanta et al. 2013). In traditional terraced landscapes there is no need to build new terraces because enough abandoned ones are available (Kendall 2012).

There are also examples of construction of modern terraces. Near the Kenyan town of Machakos, many terraces have been created since the mid-1980s, so that now approximately $70 \%$ of the cultivatable land is terraced (Thornton 1999). In Europe, newly terraced areas include the countryside around Kaiserstuhl, Germany. Because of the exceptionally erosion-prone soil, after 1950 it was necessary to terrace the slopes for intensive vineyard and orchard cultivation. When this was done, they were also adapted to mechanical cultivation (Kladnik et al. 2016).

In Slovenia, the first detailed analyses of cultivated terraces are relatively new. Ažman Momirski et al. (2008) studied the Gorizia Hills in detail, and Ažman Momirski and Kladnik (2015) presented the terraced landscape in the Brkini Hills. Terracing across all of Slovenia was studied by Ažman Momirski and Kladnik (2009), Križaj Smrdel (2010), and Kladnik et al. (2016).

The creation of the modern cultivated terraces in the Jeruzalem Hills, which are part of the Slovenian Hills, is connected with the development of viticulture. In comparison with other agricultural terraces in Slovenia, these are among the newest because they started being created only fifty years ago, under the communist social arrangement, when agricultural production there was oriented toward collective farms. None of the detailed regional descriptions of the Slovenian Hills (Belec 1968; Luskovič and Sakelšek 1994; Kert 1998), studies focusing on viticulture (Bračič 1976; Ramšak 1996; Karba 2001; Simonič Roškar 2003),

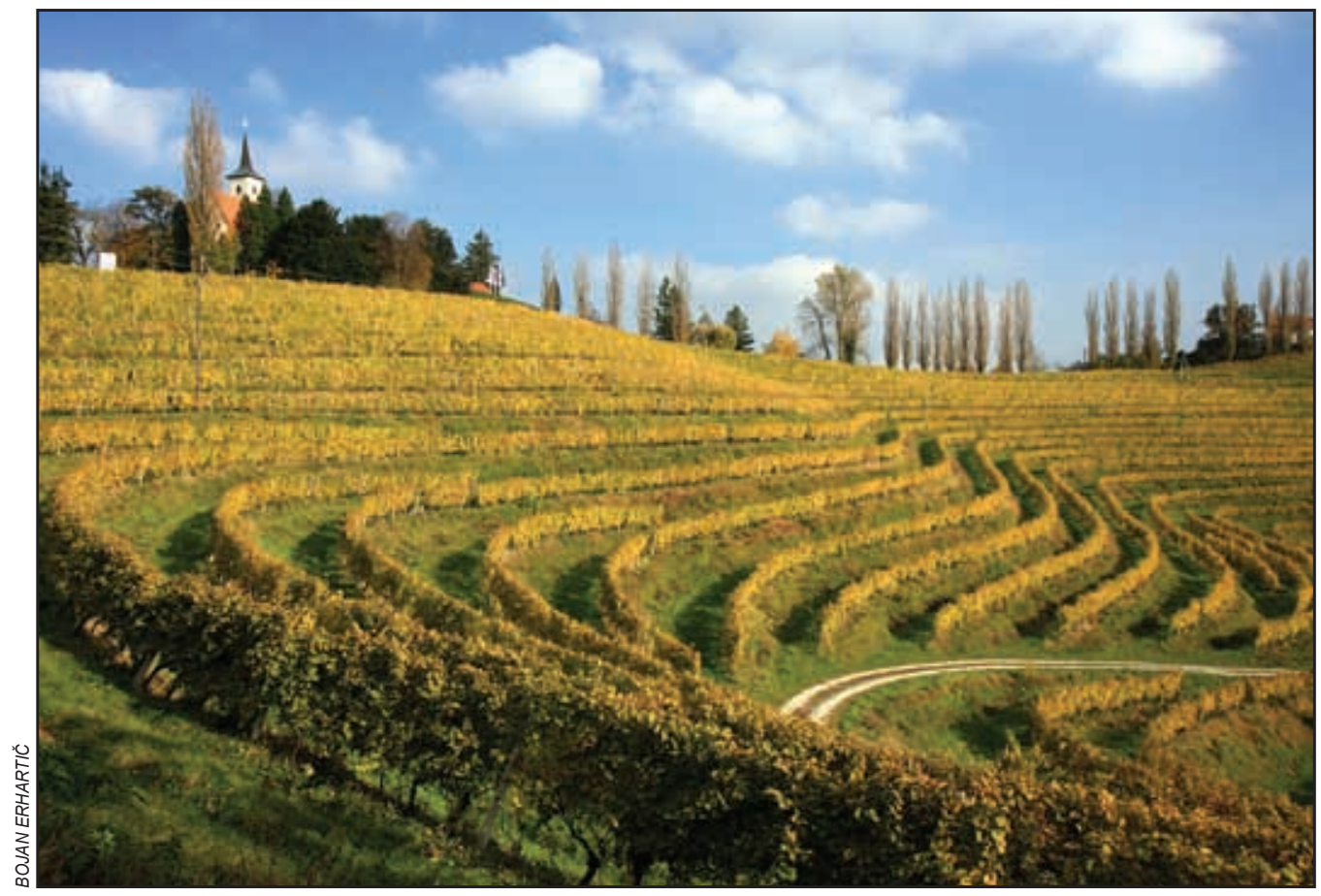

Figure 1: Terraces with individual rows of vineyards on the south and east slope below Our Lady of Sorrows Church in Jeruzalem. 
or articles about the history of the former collective farms (Oblak 2005) and land use (Žiberna 2015) have dealt in detail with the creation of the modern cultivated terraces there, nor with their transformation following denationalization, which started when Slovenia became independent in 1991. The area near the settlement of Vinski Vrh was mentioned with regard to the conversion of terraced vineyards back into vertical vineyards only by Urbanc (2002), and Erhartič (2009) evaluated the Jeruzalem terraces only from the aesthetic point of view (Figure 1).

This article provides an overview of the history of how the modern cultivated terraces were created in the Jeruzalem Hills, and it sheds light on their disappearance through the unplanned change of the terraced landscape into a state similar to its original configuration.

\section{Methods}

The study area was limited to Ljutomer Ponds-Jeruzalem Hills Nature Park (Odlok ... 1976), which lies in the Municipality of Ljutomer and covers 1,346 hectares, and the neighboring Jeruzalem-Ormož Hills Nature Park (Odlok ... 1992), which lies in the Municipality of Ormož and covers 1,911 hectares.

No research has previously dealt with this topic, and so we made use of fieldwork based on observations and four structured interviews that we carried out in the Jeruzalem Hills area with two local residents that own terraced land and with two non-owners. The questionnaire for owners contained twenty-two questions about the influence of terraces on the settlement, and their use, significance, and preservation. The non-owners were asked about the same issues, but questions about cultivating and maintaining the terraces were omitted. Two non-structured interviews were also carried out with the managers of a former

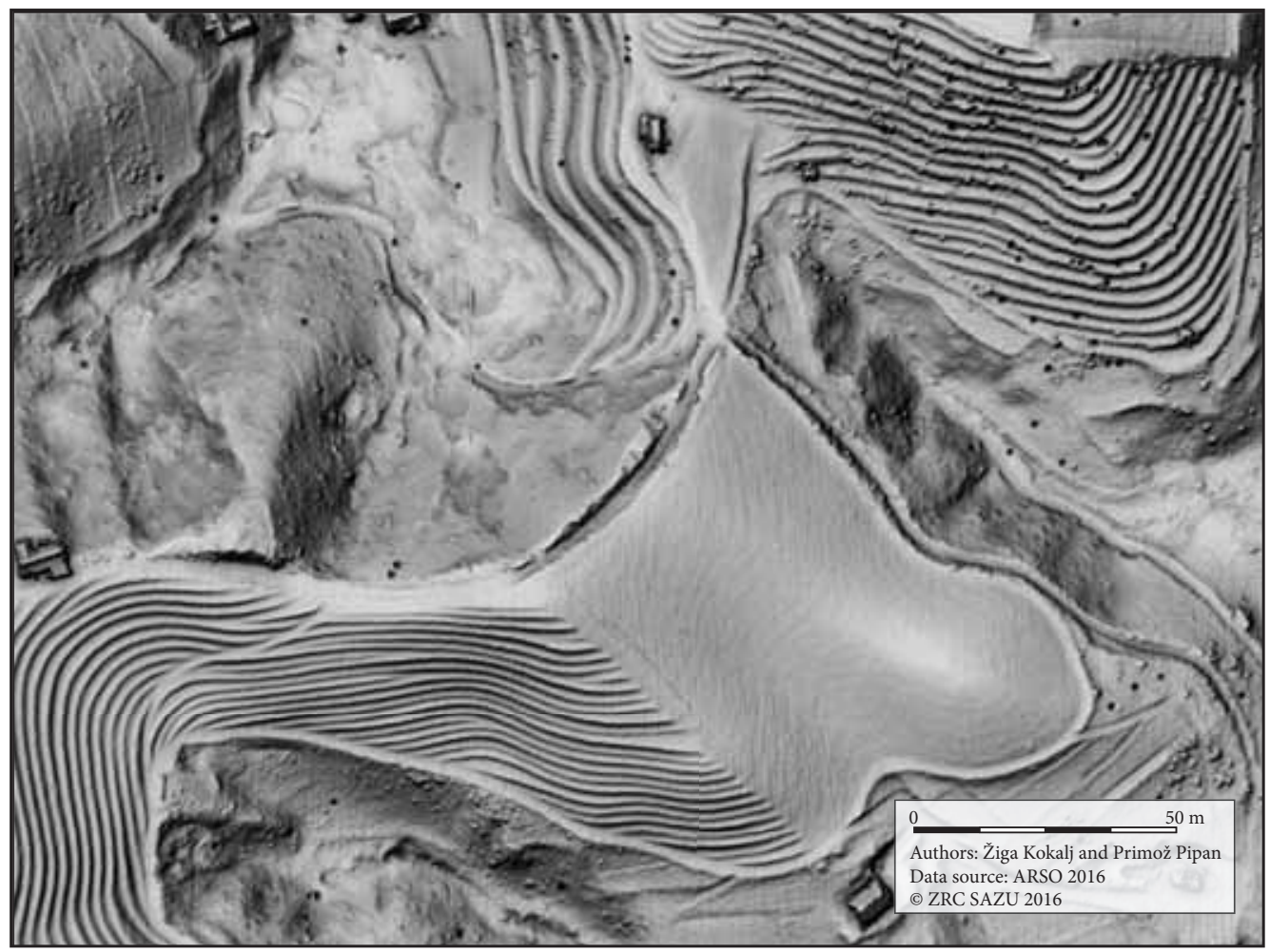

Figure 2: Lidar data make it possible to map existing terraces in detail (lower left, upper middle), including those being overgrown (upper right), and determination of the former presence of terraces where they can hardly be seen (center). 
collective farm, and information was also obtained from two experts in cultural heritage and local history. The audio recordings and transcribed interviews are kept at the Archives of the ZRC SAZU Anton Melik Geographical Institute.

The areas of the current and potentially greatest extent of modern cultivated terraces were determined through visual interpretation of information from aerial laser scanning (lidar) data, which was acquired between March $31^{\text {st }}$ and June $10^{\text {th }}, 2014$ as part of the project Laser Scanning of Slovenia. The original point cloud has a sufficient density of ground points ( 3.0 points $/ \mathrm{m}^{2}$ without repeated points) so that it was possible to rasterize it into an elevation model with a spatial resolution of $0.5 \mathrm{~m}$ and prepare an overview presentation with a combination of techniques of openness, sky-view factor, slope, and analytical hillshading (Figure 2). Such a presentation makes it possible to identify landforms, to separate between natural and anthropogenic landforms (Breg Valjavec 2014) and draw conclusions about their preservation regardless of the direction that they extend in (Kokalj, Zakšek and Oštir 2011). The pits in the terrain model (black dots in Figures 2 and 7) are a result of errors in the original data and they have not been removed.

Because of the great correspondence between the extent of existing and removed modern agricultural terraces and the areas of current vineyards, the graphic extent of vineyards from Actual Use of Agricultural Land (Dejanska ... 2012) was used for the initial stage of digitization. Based on the lidar data and recent orthophotos, the areas were then corrected, some were removed and new ones were added, and they were categorized among areas with modern terraces that still exist or potential former terrace areas (Figure 6). Determining existing terraces using lidar data is not difficult because even overgrown or damaged terraces are clearly visible (Figures 2,7B,7D).

Delimiting leveled terrace areas is significantly more difficult and was based on the information on the general geomorphological configuration of the terrain, land use, proximity of terraces still preserved, and ratio between preserved terraces, potential areas of leveled terraces, and their current use. For example, slopes that are covered by woods and have no visible terraces today were not categorized among potentially leveled land because it was concluded that the financial outlay for leveling a terrace would have been too great to simply allow it to become overgrown soon thereafter. The areas marked on the Vineyard Location Map at the Ljutomer Parish Archive were examined in detail. Potentially leveled areas were also checked on aerial orthophotos from 1997, which are already available for this period in digital form. It was anticipated that they predate the beginning of the most intensive leveling of terraces.

\section{Terracing the landscape}

This section analyzes the construction of modern vineyard terraces as a new landscape layer in the Jeruzalem Hills cultural landscape. It focuses on the situation before terracing, the process of creating terraces, and the most recent transformation of the terraced landscape into slopes without terraces. The section is based on the authors' own work, especially on visual interpretation of aerial laser scanning (lidar) data and interviews.

\subsection{The landscape before terracing}

The traditional division of the land into vineyards varied and was primarily adapted to the terrain, which man had little influence on until the modern creation of terraced vineyards. Vineyards that were accessible only for manual labor had narrow boundaries between them adapted to the inclination and individual drainage ditches for precipitation. Each vineyard tended to make the greatest use of available land, which meant not only the optimum number of grapevines planted, but also the best use of water, sun, accessibility, traversability, and ease of manual cultivation. Only old illustrations make it possible to form an idea of the variety of what were in fact vertical plantations of vines, but which today one would hardly term as such based on their appearance (Pavličič 2016). Belec $(1968,168)$ refers to them as »traditional staked vineyards « (Figure 3 ) because each vine was tied to its own stake and not connected to others with a wire support and did not form rows, so that such a vineyard differed significantly from a modern vertical vineyard, in which the vines are planted in rows with wire supports (Figure 5). 


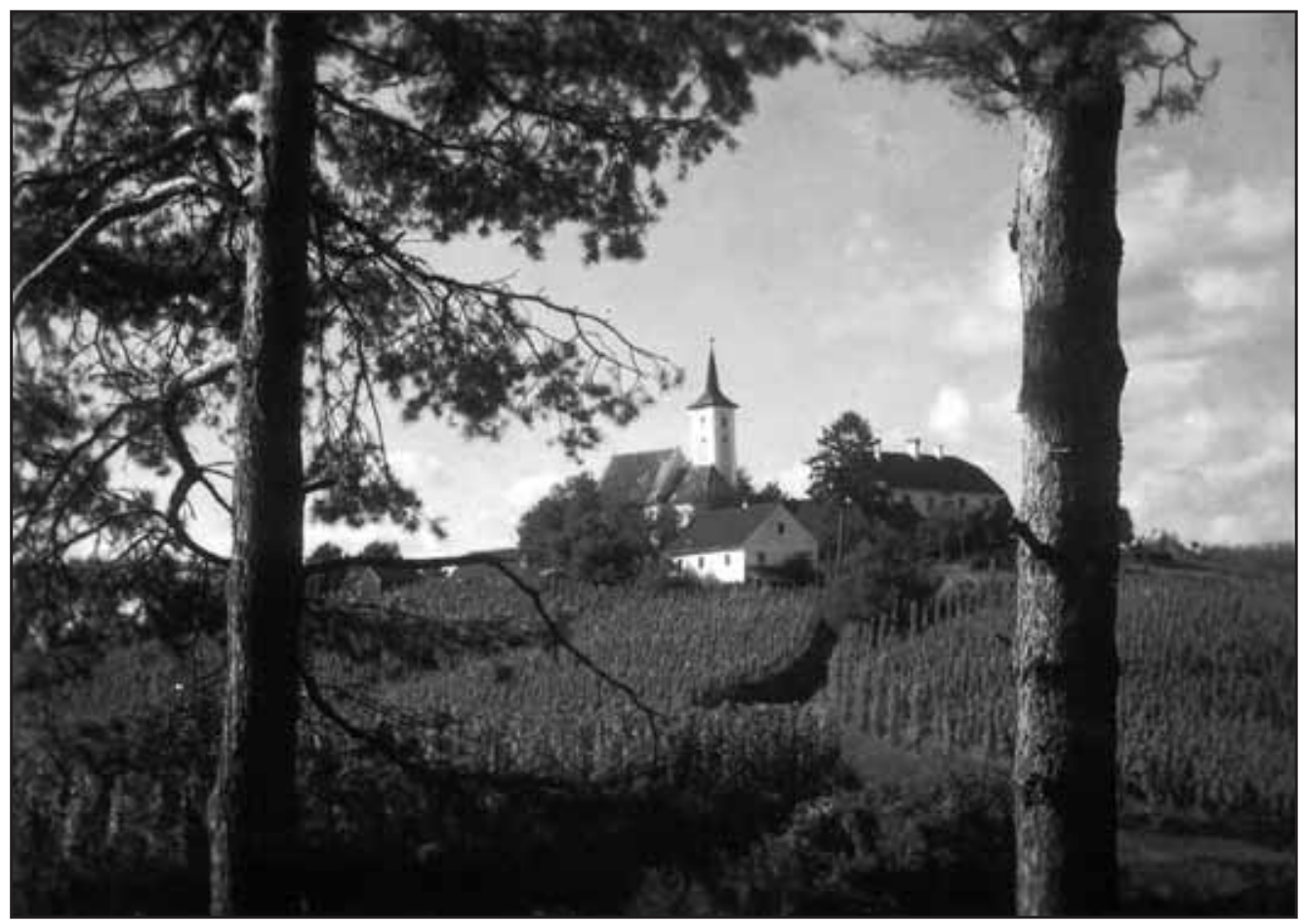

Figure 3: Around 1960 traditional staked vineyards still stood near the church in Jeruzalem (photographer unknown; kept by the Ljutomer General Library as part of its Local History Collection).

\subsection{Transforming the landscape by creating terraces}

After 1945, the former vineyard workforce sought more long-term and better-paid employment in industrialized towns. In the spirit of communist policy, factories were also built in Ljutomer, which had had an agrarian character until then, and they employed several thousand people until Slovenian independence in 1991. After the Second World War, many reforms transformed viticulture into an activity of small private vineyard owners and large viticultural cooperatives (Pavličič 2016). In Jeruzalem there was a border between two collective farms because the vineyards north of the church belonged to what later became the Ljutomer Viticultural and Livestock Collective Farm (VŽK Ljutomer) and those south of it belonged to what became the Ormož-based Jeruzalem-Ormož Collective Farm. The amalgamation of viticultural activity with regard to estates, wineries, and wine sales made a new approach possible, the most prominent aspect of which was terracing the slopes.

Two decisive factors for terracing were the lack of a labor force for manual cultivation and the limitation of agricultural mechanization at the time, which was still unable to be used on steep slopes. Thus the relatively steep slopes had to be adapted to the capacities of the machinery at that time and reshaped into terraces.

Štrakl and Žličar (2016) describe in detail the beginnings of creating the terraces. VŽK Ljutomer started preparations for terracing vineyards in 1960, when Yugoslavia was promoting agricultural development with extremely favorable bank loans; the condition for receiving a loan for the Ljutomer area was at least sixty-five hectares of territory envisaged for terracing. The expert basis for large-scale terracing was experience from the settlement of Globoka, where a terraced vineyard had already been created before the Second World War, and with vineyards on Vardovščak Hill, where terracing had been used since 1953.

Targeted aerial photography was followed by planning at Agrobiro, a Ljubljana company. The engineers Sluga and Leonardi designed the plans for terracing the Jeruzalem Hills. They started being put into 


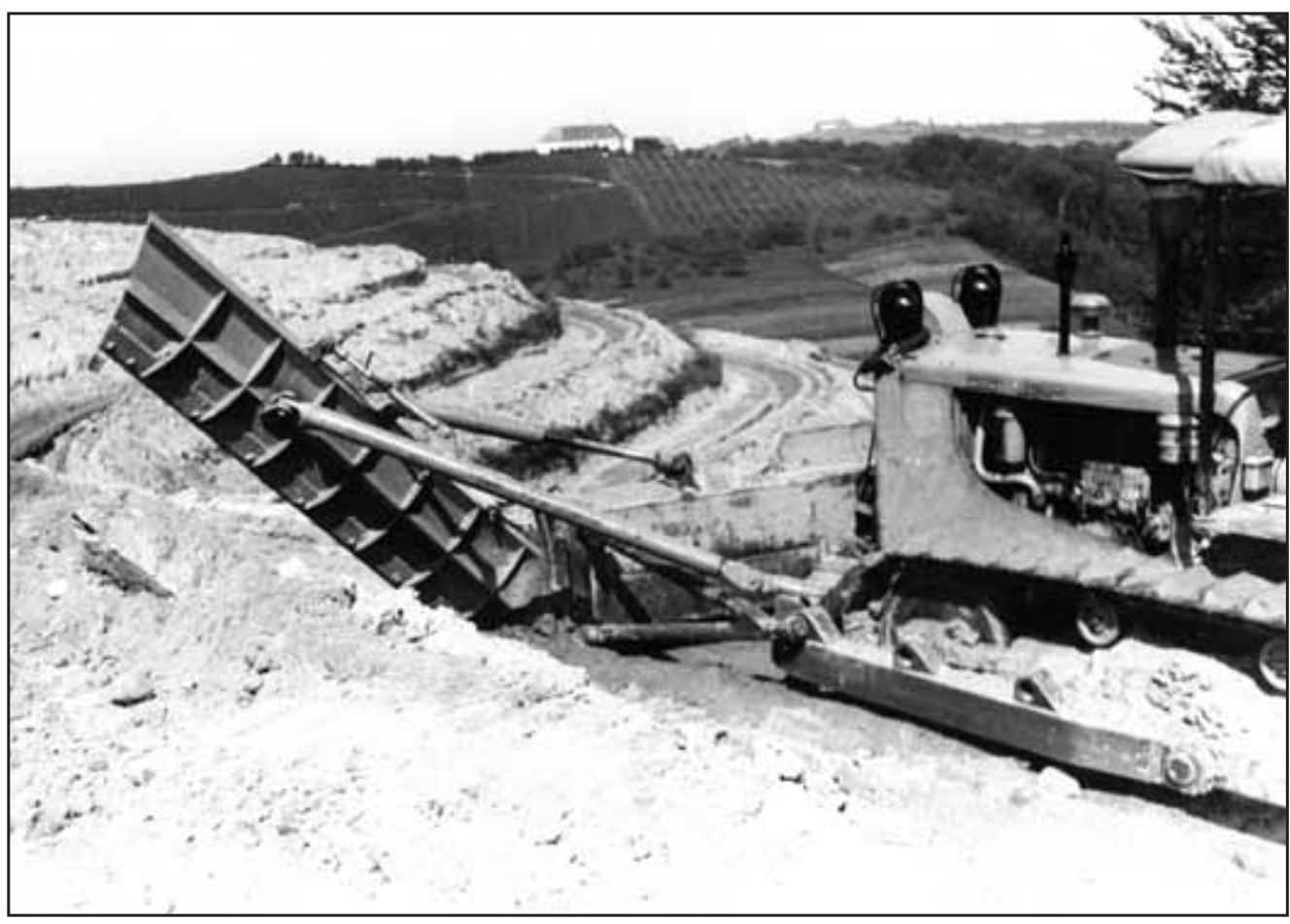

Figure 4: A bulldozer with equipment for creating terraces; Železne Dveri Mansion in the background (photographer unknown, Ptuj Historical Archives, collection:SI_ZAP/0255 Agrotransport Ptuj 1957-1997, box: 18).

effect in 1965 in the settlements of Slamnjak, Ilovci, and Železne Dveri, from which the terraces expanded toward the south and west, towards Jeruzalem. Because of the loan conditions from the Belgrade bank Poljobanka, the work for this phase of terracing had to be completed by 1969. The processes for consolidating the land and the financial part of the terracing were headed by Franc Štrakl, and the terracing at the site by Franc Žličar, both from VŽKK Ljutomer. For the initial work at the site, measurements were made by a local surveyor named Mursa. The construction was carried out by the companies Obnova Maribor and Agrotransport Ptuj because VŽK Ljutomer did not have its own machinery for creating terraces.

The terrain to be terraced was first leveled, excess vegetation was removed, and hollows and ridges were smoothed out (Figure 4). This was followed by staking out individual terraces; due to microlocation adaptation to soil quality, this did not completely follow the plan in places. Namely, problems with soil creep could occur during plowing, trenching, or leveling depending on the marl or loam content of the soil. The terrain was then worked with deep and heavy plowing, followed by the creation of variously sloped banks and leveling of platforms. An inclination of $2^{\circ}$ outwards was ensured with a three-meter batten. Some of the paths between the terraces were also adapted to actual conditions at the site. The situation was similar for the terrace banks, which were originally intended to have a $45^{\circ}$ slope but were increased to as much as $80^{\circ}$ in order to avoid losing arable land.

Calculations show that the terraced land in VŽK Ljutomer's production area yielded one-third less per hectare, although individual grapevines produced much more as a result of the introduction of new cultivars. The yield was therefore quantitatively greater than before.

Similar terracing was carried out by the Jeruzalem-Ormož collective farm (Štrakl and Žličar 2016), only that the terracing was even more intense and continued until the end of the 1980s. All available land, including the former vinedressers' private gardens, were used to create terraces. In Jeruzalem the terraces therefore extend all the way to the houses at the top of the ridges (Brenholc 2014; Vočanec 2014). 


\subsection{The latest transformation of the terraced landscape}

In the 1990s the appearance of the landscape in the Jeruzalem Hills started fundamentally changing again because of the conversion of terraced vineyards into vertical vineyards. Urbanc $(2002,173)$ determined that »among the older terraced vineyards there are appearing new or renovated ones with leveled terraces and rows of grapevines running down the slope. This arrangement allows more vines per unit area and makes mechanical cultivation of the vineyard easier. "Modern agricultural mechanization also makes possible the mechanical cultivation of steeper slopes. In comparison to terraces, vertical plantations have up to $60 \%$ more vines per unit area, which, in addition to easier and cheaper cultivation, also results in a greater profit due to both a more abundant yield and agricultural subsidies (Herga 2014; Prapotnik 2014).

Leveling terraces is most intense in Jeruzalem-Ormož Hills Nature Park, where only 190 hectares (or about 33\%) of terraces remain from their greatest extent of 570 hectares. In Ljutomer Ponds-Jeruzalem Hills Nature Park, 220 hectares (61\%) remain from their greatest extent of 363 hectares. In the southern part of the park, terraces comprise $10 \%$ of the land, and in the northern part somewhat more than $16 \%$, whereas at the time of their greatest extent they comprised $30 \%$ and $27 \%$, respectively. In the heart of the study area, terracing in the settlement of Jeruzalem is being preserved by the landowners whose vineyards were restored to them through denationalization and by the successors of both collective farms (Šmid Hribar et al. 2017).

\section{Discussion}

The terracing process, and especially the conversion of terraces back into level slopes, which was carried out over the last fifty years, shows that the landscape is dynamic and is constantly changing. Legal protection has no impact on the preservation of cultivated terraces because, based on our measurements, 56\% of them have already been leveled in the study area. We feel that that the greatest extent of terraces may

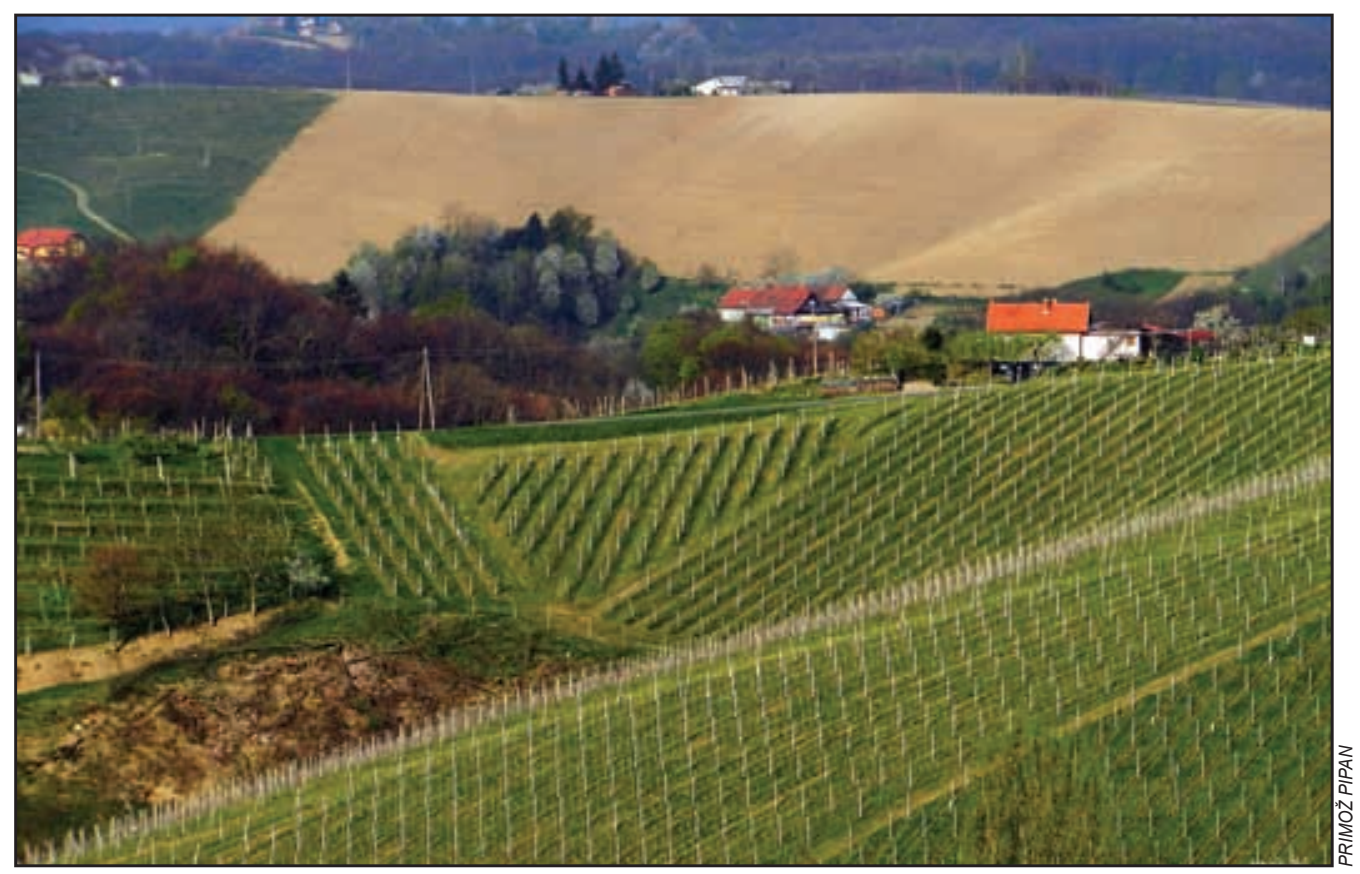

Figure 5: Relevelling the slopes with vertical vineyards with wire supports, adapted to modern mechanized farming. Remnants of terraces are visible at the lower left, and terraces were recently removed from the slope in the background. 
have been somewhat overestimated because of uncertainty in determining former terraces in certain parts, and so it would be necessary to confirm this through analysis of aerial photos from the period shortly after the terraces were created. It is interesting that the abandonment, but not destruction, of new vineyard terraces

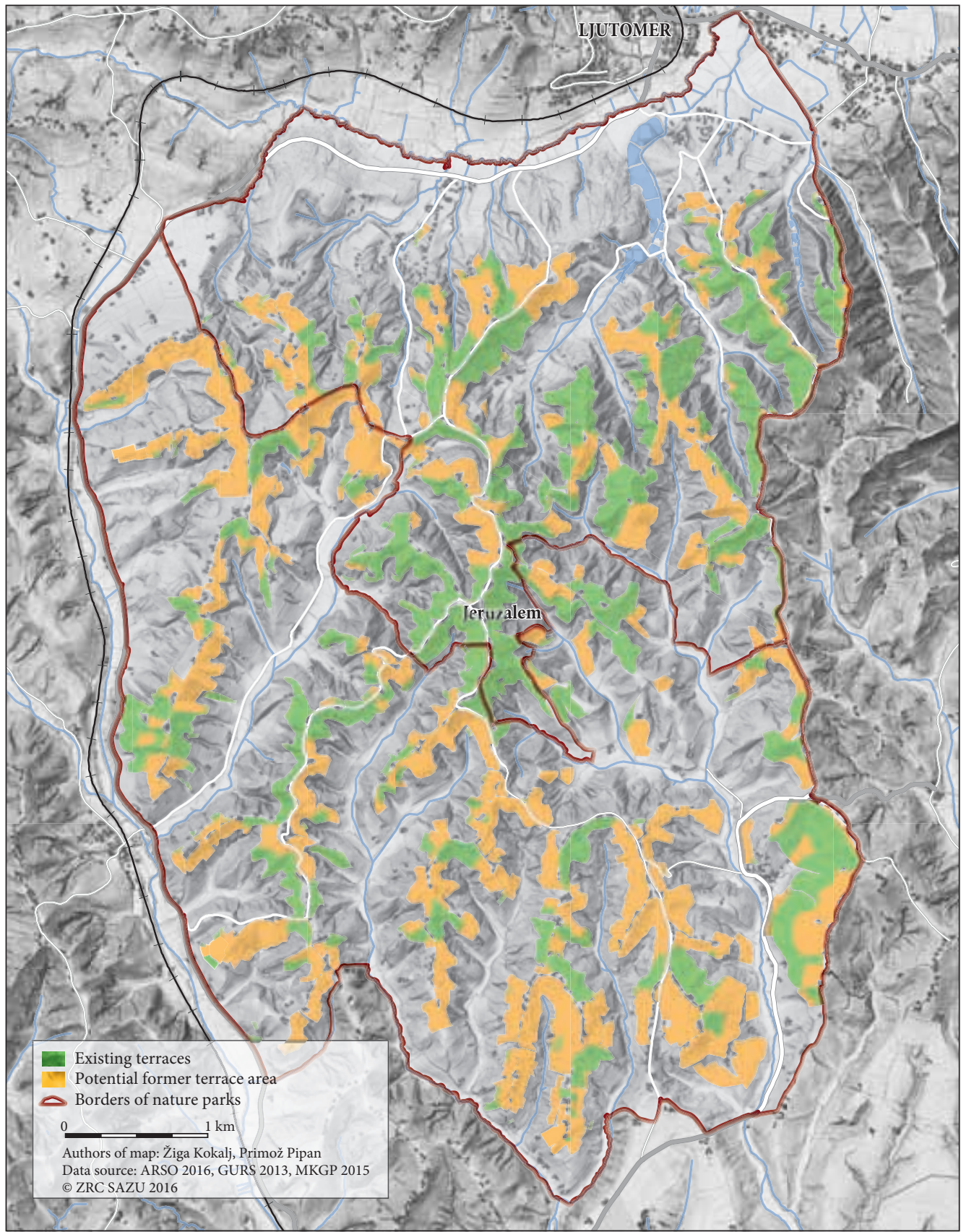

Figure 6: A large-scale map of areas where terraces still exist (green) and potential areas of former terraces (yellow). The borders of Ljutomer Ponds-Jeruzalem Hills Nature Park (northern part) and Jeruzalem-Ormož Hills Nature Park (southern part) are also shown. 
has also been ascertained in Slovakia (Špulerová et al. 2017). After 1990, 28\% of the terraces that had been created in the second half of the twentieth century in the Little Carpathians and in south-central Slovakia on slopes steeper than $6^{\circ}$ were abandoned and overgrown.

Ten years after the terraces were created, the Municipality of Ljutomer established a nature park in its part of the Jeruzalem Hills, and sixteen years later the same was done by the Municipality of Ormož. Both of these protected areas were established without an expert basis, and today they still do not have a designated manager and exist on paper only. We agree with Erhartič (2009), who argues that both nature parks were established to protect the area from construction of detached homes and vacation houses in attractive locations. Nonetheless, the terraced vineyards have become such an important element of the cultural landscape that it was due to them that the Jeruzalem Hills area has been protected as an exceptional cultural landscape (Kladnik, Šmid Hribar and Geršič 2017). The area was registered as unit number 7867 in the national Register of Immovable Cultural Heritage (Register nepremične ... 2015) with an establishment date of 1996 (Informacijsko ... 2016). When the register was revised in 2003, there was a change in protection status for this heritage unit. The category "active protection « was changed to "other, " which in practice means only documentary or archival protection without any active protection measures (Informacijsko ... 2016; Štajnbaher 2016).

The cultivated terraces in the Jeruzalem Hills are a recent manmade landscape element barely fifty years old. They initially helped people cultivate the steeper-than-average slopes, and now they are also (or primarily) valued because of their aesthetic merit. We agree with the opinion of Erhartic et al. that the general value of the landscape beauty (Smrekar, Polajnar Horvat and Erhartič 2016; Smrekar, Zorn and Komac 2016) of vineyard terraces is the main tourism asset for the Jeruzalem Hills (Erhartič 2009).

The vineyard terraces of the Jeruzalem Hills are among the main photo motifs used by the Slovenian tourism industry in many of its media campaigns to market Slovenia as a tourism destination. The profile of the Jeruzalem Hills has been enhanced precisely because of its terraces, which have become a synonym for terraced vineyards. Consequently, this area is difficult to imagine without them. Similarly to what Šmid Hribar and Ledinek Lozej (2013) determine for cultural values in Črni Vrh, we believe that in terms of cultural heritage the development potential of modern cultivated terraces can be turned into a successful product through a combination of knowledge, political will, and capable people. This is reflected, for example, in the designation of wine because in 2003 one of the wine producers used the name Terase (Terraces) for a blend of four varieties (Sauvignon, Riesling, Welschriesling, and Chardonnay). It is interesting that a wine was named after vineyard terraces in a time when these terraces have already started being leveled.

According to the interviewees, the main reasons for removing the terraces - in addition to modern agricultural mechanization, which also makes it possible to cultivate steep slopes - are denationalization and inheritance, together with the division of land connected with this. If there are several denationalization or inheritance beneficiaries, the division is simpler if the terraces are leveled because an individual parcel can be divided into several new ones. Vertical vineyards are generally planted on them because the new parcels are too narrow to set up functional terraces. In rare cases of division of terraced vineyards, the beneficiaries have divided individual terraces between themselves so that they could each cultivate their own. Terraces are also leveled in order to increase yields and the profit connected with this. According to the informants, the attractiveness of vineyard terraces is also recognized by those that leveled their former terraced vineyards and converted them into vertical plantations.

With the conversion of terraces into vertical vineyards, new challenges arose connected with increased erosion risk (Figures 7A, 7B, and 7C). There was even a case of a new owner creating completely new terraces on a slope where there had never been a vineyard in the past. Because of a lack of knowledge and experience, he unfortunately created them on unsuitable damp land, and so this soon triggered a landslip (Brenholc 2014; Vočanec 2014; Figure 7D).

Modern vertical vineyards are a new layer in the cultural landscape because this is not a return to the original configuration, before terraces were created, but a new layer on the palimpsest of the Jeruzalem Hills (Komac 2009). Namely, traditional staked vineyards (Figure 3) were characterized by a completely different arrangement of individual grapevines and drainage ditches on the slope, and by manual cultivation of the soil. Even though Antrop (2005) classifies the landscape of the Jeruzalem Hills among new European postmodern landscapes, its appearance is already fundamentally changing for a second time in 
half a century. The fact that, from the perspective of the traditional landscape these recent terraces are becoming an object of aesthetic valuation of landscape forms, despite their current disappearance, is confirmed by the findings of Urbanc et al. (2004) that preserved visible landscape elements in new circumstances can acquire new meaning for future generations.
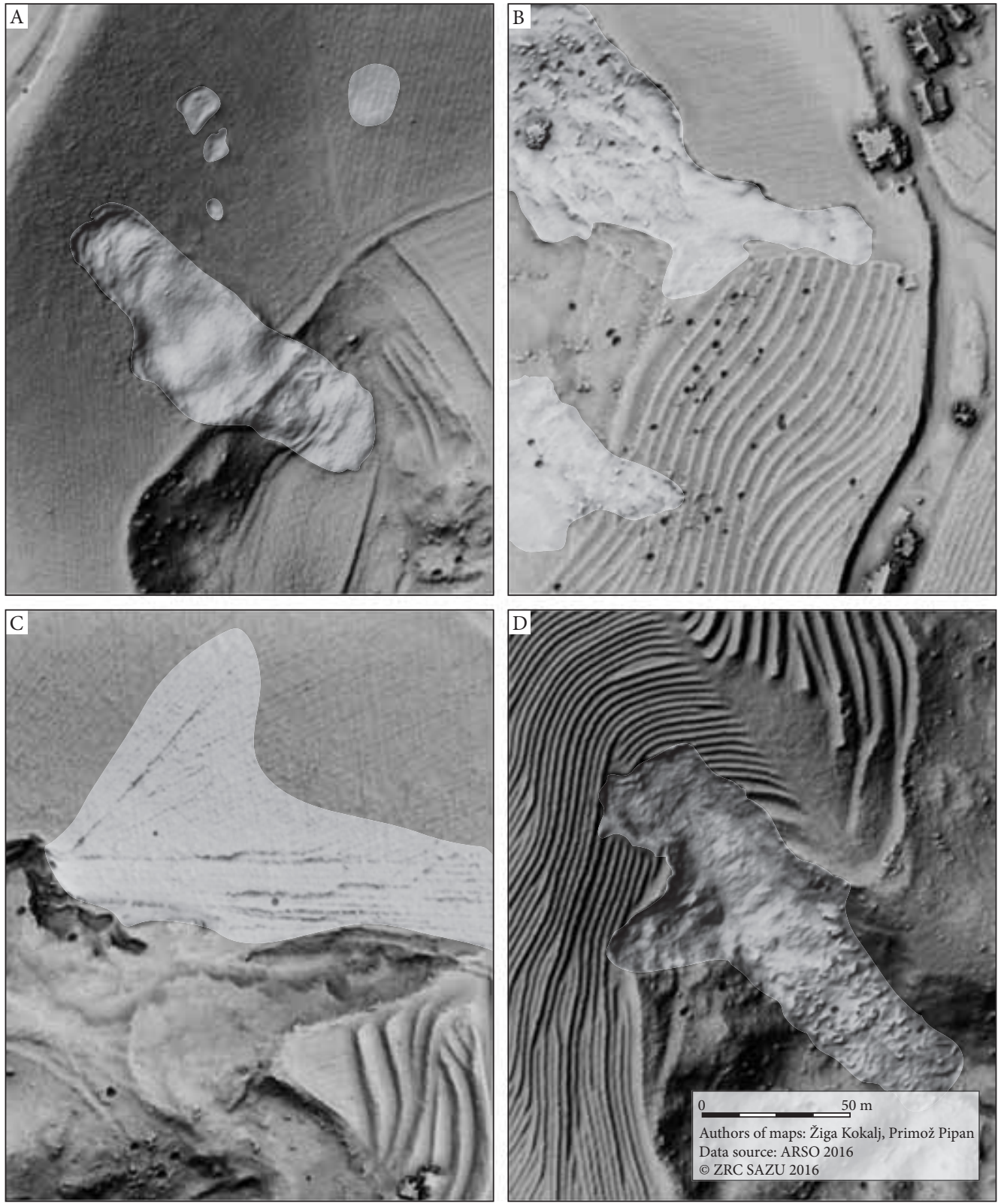

Figure 7: The removal and insufficient maintenance of terraces accelerates erosion processes such as landslides, landslips, and soil erosion, which also occur on terraced slopes. 


\section{Conclusion}

The creation of modern cultivated terraces in the Jeruzalem Hills goes back to the communist social order, which made it possible to concentrate land in two collective farms through the nationalization of farmland. The creation of this layer of the cultural landscape lasted for a quarter century - from 1965 to 1991. The extent of modern cultivated terraces was at its greatest before the transition from communism to a market economy. This is a very brief layer that has nonetheless left a very striking aesthetic impression in the landscape.

This terraced landscape, which was created at a certain point in time due to a need for greater functionality, went beyond this during its quarter century of existence and also became important because of its aesthetic value. The aesthetic aspect became more important especially after the collapse of communism, when people had become used to its new appearance after a quarter century.

Because of their outstanding aesthetic value, the terraces in the Jeruzalem Hills were also recognized by the state as worthy of protection. After the collapse of communism and the subsequent denationalization of collective farms and the restitution of farmland to its former owners, the erasure of this landscape layer of modern cultivated terraces began. Nowadays, the appearance of the landscape is drastically changing for the second time in the past fifty years. Market forces and processes have already deconstructed over half of the terraced landscape, and this trend is still continuing.

ACKNOWLEDGEMENT: The authors would like to thank Srečko Pavličič from the Ljutomer General Library and to Anton Luskovič from Kog, director of the former Ljutomer-Ormož Collective Farm, for providing valuable information.

\section{References}

Antrop, M. 2005: Why landscapes of the past are important for the future? Landscape and Urban Planning 70-1/2. DOI: http://dx.doi.org/10.1016/j.landurbplan.2003.10.002

Ažman Momirski, L., Kladnik, D., Komac, B., Petek, F., Repolusk, P., Zorn, M. 2008: Terasirana pokrajna Goriških brd. Geografija Slovenije 17. Ljubljana.

Ažman Momirski, L., Kladnik, D. 2009: Terraced landscapes in Slovenia. Acta geographica Slovenica 49-1. DOI: http://dx.doi.org/10.3986/AGS49101

Ažman Momirski, L., Kladnik, D. 2015: The terraced landscape in the Brkini Hills. Acta geographica Slovenica 55-1. DOI: http://dx.doi.org/10.3986/AGS.1627

Belec, B. 1968: Ljutomersko Ormoške gorice. Maribor.

Bračič, V. 1976: Viničarstvo. Gorice in vino. Ptuj.

Brenholc, V. 2014: Vincenc Brenholc, Jeruzalem (p.c.: 3. 4. 2014).

Breg Valjavec, M. 2014. Detection of former landfills in gravel plain using geomorphometric analysis and High-Resolution LiDAR DTM. Acta geographica Slovenica 54-1. DOI: http://dx.doi.org/10.3986/ AGS54106

Dejanska raba kmetijskih zemljišč. Ministrstvo za kmetijstvo, gozdarstvo in prehrano Republike Slovenije. Ljubljana, 2012.

Denevan, W. M. 1988: Measurement of abandoned terracing from air photos: Colca Valley, Peru. Yearbook, Conference of Latin Americanist Geographers 14. Austin.

Erhartič, B. 2009: Terase Jeruzalemskih goric kot krajinska vrednota, Pomurje - Trajnostni regionalni razvoj ob reki Muri, 20. zborovanje slovenskih geografov. Ljubljana, Murska Sobota.

García-Ruiz, J. M., Lana-Renault, N. 2011: Hydrological and erosive consequences of farmland abandonment in Europe, with special reference to the Mediterranean region: A review. Agriculture Ecosystems \& Environment 140-3/4. DOI: http://dx.doi.org/10.1016/j.agee.2011.01.003

Goodman Elgar, M. 2008: Evaluating soil resilience in long-term cultivation: a study of pre-Columbian terraces from the Paca Valley, Peru. Journal of Archaeological Science 35-12. DOI: http://dx.doi.org/ 10.1016/J.JAS.2008.06.003 
Guillet, D., Browman, D. L., D’Altroy, T. N., Hunt, R. C., Knapp, G. W., Lynch, T. F., Mitchell, W. P., OliverSmith, A., Parsons, J. R., Quilter, J., Sherbondy, J. E.,Treacy, J. 1987: Terracing and Irrigation in the Peruvian Highlands. Current Antrophology 28-4. DOI: http://dx.doi.org/10.1086/203546

Herga, M. 2014: Mitja Herga, manager of the companies Puklavec \& Friends Jeruzalem Ormož in Puklavec \& Friends Jeruzalem Ljutomer (p.c.: 2. 4. 2014).

Informacijsko dokumentacijski center za dediščino. Direktorat za kulturno dediščino. Ministrstvo za kulturo (1.7.2016).

Karba, K. 2001: Viničarstvo na Kogu. Zgodovinski listi 10-1.

Kendall, A. 2012: The importance and implications of the pre-hispanic terrace systems in the highlands of Peru: A way to food support and adaptation to climate changes. First terraced landscapes conference (Honghe - China). Kunming.

Kert, B. 1998: Slovenske gorice. Slovenija - pokrajine in ljudje. Ljubljana.

Kladnik, D., Perko, D. (ed.), Ciglič, R. (ed.), Geršič, M. (ed.) 2016: Terasirane pokrajine. Ljubljana.

Kladnik, D., Šmid Hribar, M., Geršič, M. 2017: Terraced landscapes as protected cultural heritage sites. Acta geographica Slovenica 57-2. DOI: http://dx.doi.org/10.3986/AGS.4628

Kokalj, Ž., Zakšek, K., Oštir, K. 2011: Application of sky-view factor for the visualization of historic landscape features in lidar-derived relief models. Antiquity 85-327. DOI: http://dx.doi.org/10.1017/ S0003598X00067594

Komac, B. 2009: Social memory and geographical memory of natural disasters. Acta Geographica Slovenica 49-1. DOI: http://dx.doi.org/10.3986/AGS49107

Križaj Smrdel, H. 2010: Kulturne terase v slovenskih pokrajinah. Dela 34. DOI: http://dx.doi.org/10.4312/ dela.34.3.39-60

Lasanta, T., Arnaéz, J., Ruiz Flaño, P., Lana-Renault Monreal, N. 2013: Agricultural terraces in the Spanish mountains: an abandoned landscape and a potential resource. Boletín de la Asociación de Geógrafos Españoles 63.

Luskovič, T., Sakelšek, C. 1994: Ljutomersko-Ormoške gorice. Vodnik po slovenskih vinorodnih okoliših. Ljubljana.

Oblak, B. 2005: Nastanek in razvoj Kmetijskega kombinata Jeruzalem Ormož do združitve s Slovinom. Ormož skozi stoletja 5. Ormož.

Odlok o razglasitvi in zavarovanju naravnih območij in spomenikov narave na območju občine Ljutomer. Uradne objave 14. Ljutomer, 1976.

Odlok o razglasitvi naravnih znamenitosti v občini Ormož. Uradni vestnik občin Ormož in Ptuj 37. Ptuj, 1992.

Pavličič, S. 2016: Srečko Pavličič, head librarian at the Ljutomer General Library (p.c.: 6. 1. 2016).

Prapotnik, S. 2014: Slavko Prapotnik, Kog (p.c.: 3. 4. 2014).

Ramšak, M. 1996: Življenjski pogoji viničarjev v Svečinskih goricah pred 2. svetovno vojno. Etnolog 6.

Register nepremične kulturne dediščine. Ministrstvo za kulturo. Ljubljana. Internet: http://giskd6s.situla.org/ giskd/ (1.3.2015).

Simonič Roškar, M. 2003: Viničarstvo v Halozah in Slovenskih goricah v drugi polovici 19. stol. do prenehanja viničarstva v letih po koncu druge svetovne vojne. Zbornik Pokrajinskega muzeja Ptuj 1.

Smrekar, A., Polajnar Horvat, K., Erhartič, B. 2016: The beauty of landforms. Acta geographica Slovenica 56-2. DOI: http://dx.doi.org/10.3986/AGS.3039

Smrekar, A., Zorn, M., Komac, B. 2016: Bojan Erhartič’s contribution to geography. Acta geographica Slovenica 56-1. DOI: http://dx.doi.org/10.3986/AGS.3633

Stanchi, S., Freppaz, M., Agnelli, A., Reinsch, T., Zanini, E. 2012: Properties, best management practices and conservation of terraced soils in Southern Europe (from Mediterranean areas to the Alps): A review. Quaternary International 265. DOI: http://dx.doi.org/10.1016/j.quaint.2011.09.015

Šmid Hribar, M., Geršič, M., Pipan, P., Repolusk, P., Tiran, J., Topole, M., Ciglič, R. 2017: Cultivated terraces in Slovenian landscapes. Acta geographica Slovenica 57-2. DOI: http://dx.doi.org/10.3986/AGS.4597

Šmid Hribar, M., Ledinek Lozej, Š. 2013: The role of identifying and managing cultural values in rural development. Acta Geographica Slovenica 53-2. DOI: http://dx.doi.org/10.3986/AGS53402

Špulerová, J., Dobrovodská, M., Štefunková, D., Kenderessy, P., Izsóff, M. 2017: Terraced landscapes in Slovakia. Acta geographica Slovenica 57-2. DOI: https//dx.doi.org/10.3986/AGS.4674

Štajnbaher, S. 2016: head of the Maribor branch office of the Slovenian Institute for the Protection of Cultural Heritage (Območna enota Maribor Zavoda za varstvo kulturne dediščine Slovenije) (p.c.: 1.7.2016). 
Štrakl, F., Žličar, F. 2016: Franc Štrakl in Franc Žličar, managers of the former company VŽK Ljutomer (p.c.: 6.1.2016).

Thornton, J. 1999: Sourcebook of alternative technologies for freshwater augmentation in Africa. Internet: http://www.unep.or.jp/ietc/Publications/TechPublications/TechPub-8a/ (5.5.2016).

Urbanc, M. 2002: Kulturne pokrajine v Sloveniji. Geografija Slovenije 5. Ljubljana.

Urbanc, M., Printsmann, A., Palang, H., Skowronek, E., Woloszyn, W., Konkoly Gyuró, É. 2004: Comprehension of rapidly transforming landscapes of Central and Eastern Europe in the 20th century $=$ Razumevanje hitro spreminjajočih se pokrajin v sreednji in vzhodni Evropi v 20. stoletju. Acta geographica Slovenica 44-2. DOI: http://dx.doi.org/10.3986/AGS44204

Vočanec, J. 2014: Janko Vočanec, Jeruzalem (p.c.: 3.4. 2014).

Žiberna, I. 2015: Spreminjanje rabe tal v Vzhodnih Ljutomersko-Ormoških goricah v obdobju 2000-2015 $\mathrm{v}$ povezavi $\mathrm{z}$ izbranimi fizično geografskimi značilnostmi. Revija za geografijo 10-2. 